\title{
Implementation of Pancasila in Developing National Insights During the COVID-19 Pandemic
}

\author{
Ratu Aulia ${ }^{*}$, Nuzon Sugito ${ }^{2}$, Hasmika $^{3}$ \\ ${ }^{1}$ Civic Education Department, School of Postgraduate Universitas Pendidikan Indonesia, Bandung, Indonesia \\ ${ }^{2}$ History Education Study Program, School of Postgraduate Universitas Pendidikan Indonesia, Bandung, Indonesia \\ ${ }^{3}$ Civic Education Department, School of Postgraduate Universitas Pendidikan Indonesia, Bandung, Indonesia \\ *Corresponding author. Email: ratuaulia@upi.edu
}

\begin{abstract}
National insight is an important thing that must be maintained continuously in the process of nationhood and statehood because national insight is the spirit of the spirit of national life that determines the existence of a country. However, since the COVID-19 pandemic spread to various parts of the world and Indonesia, it has been made nationalism even more vulnerable and transform the thinking of the people from collectivism to individualism so that it will threaten the existing national spirit. Pancasila as a view of life and state philosophy, Pancasila is the main tool to developing the national insight of Indonesia, as the basis of the state, Pancasila which contains noble values in its principles, both seen from each of the precepts and from a single unit of the five principles that are firmly binding. Through the implementation of the principles in Pancasila which will synergize the centralized strength of the Pancasila values (santripetal) and the strength of the elements of real behavior that spreads (sentrifugal), Pancasila is the basis and philosophy of the Indonesian state which is the source of knowledge and the noble values of Pancasila. Pancasila is able to provide solutions to every problem faced by Indonesia, by sticking to the values of Pancasila. Pancasila is expected to internalize and inspire us as citizens to stay united during the COVID-19 pandemic like today, such as sharing hand sanitizers, masks and our excess staples, so that the sustainability of the insight into the Indonesian nation will always be maintained in accordance with the problems and demands of every age.
\end{abstract}

Keywords: Pancasila, National Insight, COVID-19

\section{INTRODUCTION}

Indonesia is a sovereign country that has a wide diversity of areas, a very large demographic of Indonesia consisting of different ethnicities, tribes, cultures and traditions, this further adds to the beauty of the archipelago. located in a very strategic geographic position, making Indonesia rich in abundant natural resources so that it becomes a source of interest for foreign nations [1].

As a country that has an Eastern culture, Indonesia is filled with noble values and culture. These values are a translation of Pancasila as the unifying ideology of the nation, however, the values of Pancasila in today's society are increasingly fading due to people's disappointment with the bitter history of powers during the old order and the new order which made Pancasila a legitimate government tool. unfair policies [2], Pancasila seems to be just a symbol, without being implemented significantly both at the level of state life and at the level of community life [3] and The importance of the re-establishment of Pancasila as a way of life is an urgent matter and our main issue as the Indonesian nation [4].

In addition, the swift flow of globalization is hitting local values with pragmatic and practical values from the west, plus the current condition of Indonesia is facing a crisis in the COVID-19 pandemic. Novel Corona Virus-19 (COVID-19) is a pandemic of a new type of virus from the Corona Virus category such as SARS and MERS. This virus was first discovered in Wuhan at the end of December 2019, the virus has spread to nearly 75 percent of regencies and cities in Indonesia, and until now the positive data affected by COVID-19 is increasing every day [5].

Coronavirus or Severe Acute Respiratory Syndrome Coronavirus 2 (SARS-CoV-2) is a virus that attacks the respiratory system. This disease due to viral infection is called COVID-19. The Corona virus can cause minor disturbances to the respiratory system, severe lung infections, and even cause death. COVID-19 is a new type of coronavirus that is transmitted to humans. Although this virus mostly affects the elderly, this virus actually can affect anyone, from infants to children to adults, including 
pregnant women and nursing mothers. Corona virus infection is called COVID-19 was first discovered in China at the end of December 2019. This virus is contagious and has spread to almost all countries, including Indonesia, in just a few months. This has led several countries to make policies to impose lockdowns on some of their regions in order to prevent the spread of the Corona virus. In Indonesia itself, a Large-Scale Social Restriction (PSBB) policy was implemented to reduce the spread of this virus. Coronavirus is a virus that can infect the respiratory system. In many cases, this virus only causes mild respiratory infections, such as flu. However, this virus can also cause severe respiratory infections, such as lung infections (pneumonia). Even though it is caused by a virus from the same group, namely the type of coronavirus, COVID-19 has several differences with SARS and MERS, including in the speed of spread and severe symptoms [6].

Furthermore, Maulana notes that the spread of COVID19 is very fast, so it is better for us to know how or what symptoms are indicated by the COVID-19 virus so that we can avoid or prevent it if we find indications such as: 1) Impaired senses inhalation, shortness of breath generally appears as a sign of the disease reaching a serious stage. In fact, it can appear without a cough. Experts say, when our chest feels like it is tightened or starts to feel difficult to breathe, this is a sign we must act quickly. The Centers for Disease Control and Prevention (CDC) has described other emergency signs when infected with COVID-19. The signs of an emergency are: (a) persistent pain or pressure in the chest; and (b) lips or face become bluish which indicates a lack of oxygen intake; 2) Fever, is one of the key signs of COVID-19. Experts do not determine the number of fever temperatures experienced. The reason is that everyone can have a fever temperature that is different from the normal body temperature benchmark; 3) Cough, is a common symptom of corona virus infection. However, the cough that appears is not an ordinary cough, although dry cough is a sign, but a report from the WHO in February 2020, said that 33 percent of the 55,924 people with COVID-19 had a cough with phlegm or thick mucus which is sometimes called phlegm; 4) The danger sign of COVID, in some patients, when conditions worsen, they experience a number of emergency conditions. The CDC warns that if the body is unable to get up or get out of a lying position, or loses its response, this could be a serious sign that we need immediate treatment. If a person exhibits the above symptoms accompanied by blue lips, difficulty breathing, and chest pain, they should seek help immediately; and 5) Disturbance to the senses of smell and taste, loss of ability to smell and taste can be unusual symptoms for people with COVID-19 with mild to moderate levels of cases [7]. Some experts say, anosmia, which means loss of smell, was found to be one of the symptoms experienced by a number of patients. This also reduces the sufferer's appetite. According to the American Academy of Otolaryngology-Head and
Neck Surgery, anosmia has been found to occur in COVID19 positive patients who do not experience other symptoms. A new analysis of mild cases in South Korea also shows the same thing. About 30 percent of patients lose their ability to smell.

According to Widisuseno and Sudarsih [6] with a crisis in the midst of society, people's thinking will be transformed, one of which is the transformation of "collectivity" thinking into "individuality" thinking. The transformation of people's thinking is the impact of the decline in national insight on each individual as an Indonesian citizen, even though it is the thought of collectivity and togetherness that strengthens us as the Indonesian nation, but collectivity starts to become fragile because we panic and suspect each other due to the continuous increase of people who positive for COVID-19. By transforming people's thinking, it will be easy to use by organizations with other ideologies to campaign for their existence. This can be seen from the scattering of the PKI logo with the hammer and sickle in several parts of Indonesia and the issues of the PKI movement that emerged amid the COVID-19 pandemic [8].

The issue of national insight is actually not a new problem, but long before the COVID-19 pandemic, the youth congress in 1908, then the youth oath in 1928, and the proclamation of independence in 1945 were all carried out, one of the goals was to form an insight into the nation of Indonesia. In addition, in 2011 the Central Statistics Agency (BPS) conducted a survey on the love of the people for the Unitary State of the Republic of Indonesia (NKRI), from the survey results found $69.80 \%$ of the people said their lack of love for the Republic of Indonesia [9]. However, the COVID-19 pandemic could exacerbate existing conditions. This requires the mastery of national insight for all Indonesian people in realizing a society that is able to understand global problems and has the ability to resolve conflicts constructively, recognizes the way of life with international standards regarding equality of human rights and race and respects cultural diversity in the unity of the world [10]. Apart from that the national insight also creates a spirit and a sense of nationality as the main strength and fighting power in maintaining the nation's dignity not only limited to the political process but also involves all life processes (social, economic, artistic, moral and so on)[11].

National insight is a perspective in seeing the selfexistence of a nation in the context of being a complete entity and in the context of reciprocity from the surrounding environment [12]. In essence, the national insight is related to the westphalian state concept with three main characters, namely the concept of sovereignty, the concept of equality and the concept of not interfering in other people's affairs (nonintervention) [11]. In the context of Indonesia, the insight of the archipelago was born together with the concept of love for the country and diversity in unity. As according to Martadirdjo, the insight into Indonesian 
nationality is formed from a process that is deeply rooted in demands for a sense of humanity and justice against the arbitrariness of colonialist domination on the lives of the Indonesian people [12]. The national insight of Indonesia in history was formed from the formation of the Budi Utomo national movement organization in 1908, then at the youth oath on October 28, 1928 which was represented by various youths with ethnic group backgrounds and vowed to shed the blood of one Indonesian homeland, one nation and one Indonesian nation [3] and upholding the language of the unity of the Indonesian language, then the determination of the youth was continued by the struggle during Indonesian independence until the proclamation of Indonesian independence on 17 August 1945.

According to Moerdani there is a three-dimensional national vision including national sense, national understanding and national spirit. From the national vision will form the orientation, perception and behavior that is lived by all Indonesians, from this appreciation will be the life of the nation and state and bring success to the future of Indonesia [13]. Indonesia's national vision is rooted in Pancasila and the 1945 Constitution as the basis of the Republic of Indonesia (NKRI) and should be the solution to all problems faced from all ages. The purpose of writing this article is that the author would like to see the implementation of Pancasila as a view of life and national philosophy in growing national vision during the COVID19 pandemic.

\section{METHOD}

This research uses a qualitative approach. As according to Creswell qualitative research is a process of exploring the exploration of problems and developing a detailed understanding of central phenomena [14]. Qualitative means something related to the aspect of measuring the quality, value or meaning contained in a fact or phenomenon. The research method used is descriptive analytical method which is carried out by looking for relevant data with the discussion of the implementation of Pancasila in developing national insight during the Covid19 pandemic, analysis is carried out to produce new ideas in developing national insight during the Covid-19 pandemic.

\section{RESULT AND DISCUSSION}

\subsection{Implementation of Pancasila in Developing National Insights during the COVID-19 Pandemic}

The national insight is essentially a view or point of view that reflects the attitude and personality of the Indonesian people who have a love for the country, uphold unity and unity, have a sense of togetherness as a nation to build Indonesia towards a better future, amidst global competition. Globalization and the current attack of the COVID-19 pandemic, without losing the cultural roots and basic values of Pancasila that we already have. As stated in article 1 number 1 Permendagri No. 71 of 2012 concerning National Insights Education Guidelines, namely the perspective of the Indonesian nation about itself and its environment prioritizing national unity and integrity as well as territorial unity based on Pancasila, the 1945 Constitution of the Republic of Indonesia, Bhinneka Tunggal Ika, and the Republic of Indonesia [15].

National insight includes both an inside and an outside insight. Inward insight means looking at the Indonesian nation itself, which has a large territory of the country, a large population, cultural diversity and others, must be put in one view that is based on the common interest as a nation. Outward insight, namely looking at the environment around neighboring countries and the international world. The Indonesian nation must have strong integrity and credibility in playing its role in the international world as a sovereign and dignified nation. Wildan argues that "the national insight is essentially the same perception of all components of the Indonesian nation as the basis for building a high national feeling and enthusiasm in all. aspects of national life [16]. The national insight will be the driving force to do, present, and dedicate the best work for the nation and state. National insight can be interpreted as a perspective of person or group of people to understand existence identity as a nation and behave in accordance with the philosophy of national life in the internal and external environment. More than that, the nature of the national insight requires having the attitude to immediately end loyalty to groups (parties, groups, ethnic groups) or individuals once loyalty to the nation and state is needed" [17].

As we all know that the national spirit and insight are important to be cultivated, because the sense of nationality as a manifestation of love for the country, in turn awakens our awareness of the meaning of being expensive and valuable to the sense of unity and unity of this nation". As expressed by Lemhanas National insight as an actualization of the basic values of national awakening needs to be transmitted to all Indonesian people across generations to strengthen the nation's resilience in the era of globalization [18]. This is because the National Insight is the perspective of the Indonesian nation based on Pancasila and the 1945 Constitution of the Republic of Indonesia regarding themselves and their environment in expressing the national identity in the midst of the world order of life. The national insight also reflects the desire of the Indonesian nation as an independent, united, sovereign, just and prosperous nation in togetherness to overcome all obstacles and challenges, both from outside and from within the country, including a sense of togetherness in facing the threat of separatism and radicalism that can endanger unity and national unity. Maliki argues that "the development of national insight is 
something very important in an effort to build social cohesion amidst a pluralistic national population and moreover being overshadowed by the threat of ethnic and religious conflicts" [11].

Every nation in the world has a way of looking at its own nationality and homeland, and this perspective on nationality is then referred to as a national insight. The Indonesian nation has its own national insight that is in accordance with the values of Pancasila. As the official ideology of Indonesia, Pancasila that encapsulates principles of religious tolerance and pluralism [19]. Based on these values, the Indonesian people have a perspective to move forward in achieving national goals. Maliki argues that "the national insight is a perspective that can provide a foundation for the nation's children in building social cohesion and an agreement to live together. in the middle of a country that has thousands of islands, a plurality of ethnicities, languages, cultures, informal ideologies and religions" [11]

According to Isabella argue that national insight where emanates from Pancasila will be able to be internalized in the community through the following: (1) vision on a national mandate to all nations to place the unity, interests and safety of the nation above individual or group interests;

(2) Vision nationality gives no place to cunning patriotism;

(3) The national perspective builds Indonesian unity, this unity is a manifestation of the principle of Bhineka Tunggal Ika maintained well; 4) vision to be determined to create a progressive and independent one prosperity of the nation and inner and outer, equal to others developed countries; 5) based on the national vision in the philosophy of life Pancasila, the Indonesian nation will managed to find a smooth path in the life of a good state [17].

Thus, the national insight becomes important to be instilled in every citizen of Indonesia, because it needs to be disseminated to all levels of society continuously, not only as a momentary movement, but must be pursued on an ongoing basis. National insight that is often promoted by the government, should not be just verbal rhetoric that has never been actualized in reality. However, the nationalism insight must be truly realized in real everyday life, especially in the midst of the current COVID-19 pandemic in order to become the unity and integrity of Indonesia to become stronger.

We, as citizens of Indonesia, must apply the spirit to the values of Pancasila as the view of the Indonesian people, there is no idea of a theory that contradicts strength or power in explaining the understanding of national insight, because the theory that opposes power or power contains the embryo of dispute and expansionism. The view of the Indonesian people emphasizes how to ensure the unity and integrity of the nation (inside) and uphold the interests of the nation and state in the world forum (outside), especially in a situation like today where the country is being attacked by the COVID-19 pandemic [20]
Pancasila is the basis and philosophy of the Indonesian state which is a source of knowledge and noble values. As in it there are basic values, instrumental values, practical values, and technical values, in accordance with the first dictum of the MPR-RI Decree Number XVII / MPR / 1998 that Pancasila must be implemented continuously in the life of the Indonesian nation and state [21]. In the context of developing an insight into the nationality of Indonesia during the COVID-19 pandemic, Pancasila is related to the cultural phenomenon of the multi-ethnic Indonesian people, the values contained in Pancasila will continue to illuminate every life of the nation and state. In the process of implementing Pancasila values, the binding power is not only centralized (santripetal) but also has centrifugal power [12].

At present, the government is making efforts in order to rejuvenate the insight of Indonesian nationality, several efforts that can be done are by [22]:

a) Increase awareness of all components of the nation to accept, respect and appreciate all forms of diversity.

b) Developing attitudes, morals and ethics for all components of the nation in accordance with Pancasila and the 1945 Constitution.

c) Increase the socialization of national insight in order to build a harmonious national life.

d) Optimizing national insight learning that is in line with the reform process and is not indoctrinated.

e) Building noble cultural values based on national insight to build a spirit of regional autonomy.

f) Increase respect for state symbols.

g) Increase the role model of national leaders.

By carrying out the above efforts, the nationalism insight can guarantee the achievement of the national interest. During the COVID-19 pandemic, the government imposed a Large-Scale Social Restriction (PSBB) policy, which required the Indonesian people to maintain physical distancing. This is a decision taken to control the COVID19 pandemic, this is in accordance with the mandate in the preamble of the 1945 Constitution of the Republic of Indonesia which reads "to protect the entire Indonesian nation and all Indonesian blood to advance public welfare, educate the nation's life and carry out world order". This requires every citizen to support every policy taken by the government in order to protect the entire Indonesian nation. In addition, it is hoped that every Indonesian citizen is capable and willing to sacrifice for the benefit of the nation. In this regard, respect for human dignity, love for the motherland and the nation should be fostered. By internalizing the values of Pancasila and sticking to the values of Pancasila, with the insight of nationality, it should be able to develop Indonesian unity in such a way that the principle of diversity is maintained. Unity must not kill diversity and plurality. On the other hand, diversity and 
plurality should not become divisive but become a force that enriches unity.

Pancasila as a way of life and way of life (weltanschauung / weldbeschauung) is the basis for the government in determining every policy, including policies taken during the current COVID-19 pandemic. Pancasila in the first principle of "God Almighty" which is a manifestation of the diversity of religions and beliefs in Indonesia, which respect each other between religions and are united in differences, religions and beliefs are mobilized by one or more religious leaders who, if we associate it with the pandemic COVID-19. The leaders of a religion are not only limited to giving advice, advice and advice to calm the people. As Gultom views that religious leaders should not be trapped in ontotheological sermons, lectures and suggestions which lead to the conclusion that this pandemic is a trial from God and we as religious people only increase repentance, the actions of religious leaders like this only sharpen the meaning responsibility in the community [23]. But more than that, religious leaders can go beyond sharpening the meaning of this responsibility, something that religious leaders can do by recording their reactive followers of the COVID-19 pandemic. This activity can be carried out by collaborating with religious leaders and places of worship with government health agencies equipped with competent health personnel so that places of worship are not only a means of connecting people with God but are also able to provide facilities for prevention and early detection of the spread of the COVID-19 pandemic.

Pancasila in the second principle of "Just and Civilized Humanity" explicitly explains to us and policy makers to prioritize humanity above all short-term interests alone, Anas argues that all kinds of actions lead to efforts to hinder prevention, treatment and treatment must be eradicated, such as mask hoarding selling masks at high prices, and there may be irregularities in policies that are not fair to the public [24]. This is important for the community in understanding the second principle of Pancasila, because if the community is inspired, the values of the nation will make people able to make good decisions to stay at home and carry out physical distancing during the critical period of the COVID-19 pandemic so that it does not harm other communities.

Pancasila in the third principle of "Indonesian Unity" directly advises every Indonesian citizen to unite and together in fighting the COVID-19 pandemic by prioritizing health protocols that have been recommended by the government, prioritizing common safety compared to the interests of individuals, groups and groups. The war against the COVID-19 pandemic is a joint war, not just a war between health workers, but all stockholders must play a role in accordance with their respective abilities and professions so that Indonesia can win this war.

Pancasila in the fourth principle, "Democracy Led by Wisdom in Deliberation / Representation" directly shows how the government and policy makers should consider every policy to be decided. In the context of the COVID-19 pandemic, there is a dilemma between choosing to defend the country's economy or the safety of its people, this requires in-depth study and consideration and involving stakeholders so that policy makers are truly able to address problems during the COVID-19 pandemic appropriately.

Pancasila in the fifth principle "Social Justice for All Indonesians" explains that during the COVID-19 pandemic the government and citizens must be fair, for example by not doing panic buying that buys excess stocks of basic necessities and masks, this can result in part of the community did not get stocks of basic necessities and masks so that it tormented other people. The COVID-19 pandemic has also resulted in a halt in the production process at companies, this has resulted in a massive majority of workers and private employees being forced to work. The Indonesian government provides a solution by distributing assistance for the living costs of people affected by the COVID-19 pandemic, but some people reject this assistance because they think that there are still many who need more of the family, this is because the family implements the fifth principle of Pancasila.

\subsection{Our Contribution}

This paper presents how to implement Pancasila in developing nationality insight the people of Indonesian on this COVID-19 pandemic, this paper also examines one by one the existing principles of Pancasila along with actions that manifest Pancasila in the form of national insight during the COVID-19 pandemic health crisis.

\subsection{Paper Structure}

The rest of this paper is orginized as follows: Part 1 introduces the background to the writing of this paper, where the author wants to see the importance of developing national insight during the COVID-19 pandemic. Section 2 presents the methods used in the process of compiling the results and discussion. Then, in Section 4 the results and discussion, which discusses how to implement Pancasila in developing national insight during the COVID-19 pandemic. Section 5 concludes the paper and provides directions for future research.

\section{CONCLUSION}

Through the implementation of the principles in Pancasila which will synergize the centralized strength of the Pancasila values (santripetal) and the strength of the elements of real behavior that spread (sentrifugal), Pancasila is able to provide solutions to every problem faced by Indonesia. Pancasila is expected to be able to 
internalize society with its noble values during the COVID19 pandemic. Pancasila inspires us as citizens to work together during the COVID-19 pandemic to strengthen and encourage each other, to share hand sanitizers, masks and our excess staples, so that the sustainability of the insight into the Indonesian nation will always be maintained in accordance with the problems and demands of every age. Where the national insight of Indonesia also mandates the entire nation to place unity, integrity, and the interests and safety of the nation and state above personal and group interests, especially in the current conditions of the COVID19 pandemic.

\section{ACKNOWLEDGMENT}

This article is supported by Nehlah, S.Pd., because she has provided suggestions so that the authoress can complete this article. Then, the authors also conveys to Ah. Djuanda, S.Pd as proofread of this article and the committee The International Conference on Character Education (ICCE) University of Muhammadiyah Semarang as a reviewer for this article.

\section{REFERENCES}

[1] Daniarti, R. (2017). Implementasi Nilai-Nilai Pancasila Sebagai Pendukung Tumbuh Kembang Wawasan Kebangsaan Pada Mata Pelajaran PPKn di SMP Negeri 7 Palembang. Jurnal Manajemen, Kepemimpinan, Dan Supervisi Pendidikan Volume 2, No. 2, Juli-Desember 2017.

[2] Harefa, A. (2007). Implementasi Pancasila Sebagai Dasar Filsafat dalam Kehidupan Berbangsa dan Bernegara. Jurnal Ilmiah Pendidikan Humaniora, Sains Dan Pembelajaran ; Didaktik, Oktober 2007.

[3] Maftuh, B. (2008). Internalisasi Nilai-Nilai Pancasila dan Nasionalisme melalui Pendidikan Kewarganegaraan. Jurnal Educationist Vol. II No.2

[4] Afryan, Sapriya, (2018). Internalisasi Nilai-Nilai Pancasila Melalui Pusat Studi Pancasila Sebagai Upaya Penguatan Ideologi Bangsa Bagi Generasi Muda (Studi Kasus Di Pusat Studi Pancasila Universitas Gadjah Mada Yogyakarta). UCEJ, Vol. 3 No. 2, Desember 2018, Hal. 158-167
[5] Safrizal ZA, Putra D.I, Sofyan S, Bimo, (2020). Pedoman Umum Menghadapi Pandemi COVID-19 Bagi Pemerintah Daerah; Pencegahan, Pengendalian, Diagnosis Dan Managemen. Jakarta : Kemendagri.

[6] Widisuseno Iriyanto dan Sri Sudarsih. (2019). Penguatan Wawasan Kebangsaan Sebagai Upaya Pencegahan Paham Radikalisme dan Intoleransi Di Kalangan Pelajar Sekolah Menengah Atas Negeri 3 Salatiga Kotamadia Salatiga. Jurnal "HARMONI", Volume 3. Nomor 1, Juni 2019.

[7] Maulana, M., F., (2020). Bela Negara Para Pemuda Milenial dalam Menanggapi COVID-19 (Defend Millennial Youth Countries in Responding to Covid-19). Ewha Journal of Social Sciences, Forthcoming, 2020.

[8] Mansur, A. (2020). Isu Gerakan PKI Muncul di Tengah Badai COVID-19. Diakses pada 2 Juni 2020 pukul 00.32 WIB di Republika.co.id/amp/qb0xq1377.

[9] Badan Pusat Statistik, (2011). Laporan Survei Pandangan Masyarakat Terhadap Kehidupan Bernegara. Jakarta.

[10] Bahri H.S, Sapriya, Halimi M., (2018). Penguatan Wawasan Kebangsaan Generasi Muda Melalui Kegiatan Tadarus Buku. Jurnal Civics: Media Kajian Kewarganegaraan Vol. 15 No. 2 Tahun 2018| 126-133.

[11] Maliki, Zainuddin, (2010). Sosiologi Politik: Makna Kekuasaan dan Transformasi Politik. Yogyakarta: Gajah Mada University Press.

[12] Martodirdjo, H.S., (2008). Implementasi Pancasila dalam Menumbuhkembangkan Wawasan Kebangsaaan. Jurnal Ketahanan Nasional XIII( 2), April 2008.

[13] Wahyono, S.K., (2007). Wawasan Kebangsaan dalam Wadah Negara Kesatuan Republik Indonesia. Jurnal Ketahanan Nasional xii(2), Agustus 2007.

[14] Creswell, J., (2015). Riset Pendidikan : Perencanaan, Pelaksanaan, dan Evaluasi Riset Kualitatif \& Kuantitatif. Yogyakarta: Pustaka Pelajar.

[15] Permendagri Nomor 71 Tahun 2012 tentang Pedoman Pendidikan Wawasan Kebangsaan.

[16] Wildan, Dadan, (2009). Pendidikan Wawasan Kebangsaan di Era Reformasi Gelombang Kedua Untuk Mewujudkan Visi Indonesia 2015. Jurnal Sekretariat Negara Republik Indonesia, (14), hal :150-164. 
[17] Isabella, (2017). Strengthening The National Resilience of Indonesia Through Socialization of National Insight. Advances in Social Science, Education and Humanities Research (ASSEHR), volume 163. Atlantis Press.

[18] Lemhanas, (2013). Aktualisasi Semangat Kebangkitan Nasional Guna Memantapkan Wawasan Kebangsaan Lintas Generasi dalam Rangka Ketahanan Nasional. Jurnal Kajian Lemhannas RI, Edisi 15, hal : 30-40.

[19] Fossati, D., Aspinall., E, Muhtadi, B., Warburton., E., (2020). Ideological Representation in Clienistic Democracies: The Indonesian Case. Electoral Studies 63 (2020) 102111

[20] Mahipal, (2011). Membangun Keutuhan Negara Kesatuan Republik Indonesia Melalui Pembinaan Ideologi Dan Wawasan Kebangsaan (Building Integrity of the Republic of Indonesia through the Ideology Development and National Insights) (March 13, 2011). Jurnal Pedagogia FKIP Universitas Pakuan, 2011.

[21] Sutono, A., (2015). Meneguhkan Pancasila sebagai Filsafat Pendidikan Nasional. Jurnal Ilmiah Civis, Volume V, No 1, Januari 2015.

[22] Ahmad S., (2017). Transformasi Pendidikan Pancasila dan Wawasan Kebangsaaan Bagi Generasi Milenial Untuk Revitalisasi Anti Korupsi . Jurnal Salam: Jurnal Sosial \& Budaya Syari Vol. 4 No. 1 (2017), pp. 43-56, DOI: 10.15408/sjsbs.v4i1.7868.

[23] Gultom, A.F., (2020). Filsafat, Corona, dan Kepanikan Kita. Diakses pada 1 juni 2020 pukul 22.00 WIB di https://www.researchgate.net/profile/ Andri Gultom/publication/340091676_Filsafat_Corona_dan Kepanikan_Kita/links/5e779da5299bf1892c01fdaf/Fils afat-Corona-dan-Kepanikan-Kita. pdf?Origin=publication_detail.

[24] Anas, M., (2020). Etika Sosial Pancasila dan Kebijakan Wabah Corona. Di akses pada 2 Juni 2020 pukul 01.03 WIB di http://macapat.pmpk.ub.ac.id /etikasosial-pancasila-dan-kebijakan-wabah-ko rona/. 